\title{
Sprogskiftet og nogle stednavnetyper i Sønderjylland
}

\author{
Af Wolfgang Laur.
}

Som vi ved, bliver stednavne overtaget fra det ene sprog til det andet. Derfor er vi også $i$ stand til at rekonstruere et uddødt sprog på grundlag af de overleverede stednavne, f. eks. illyrisk, pelasgisk og de ikke-indoeuropæiske f $\varnothing$ rgræske sprog i det gamle Hellas. Men stednavnene forbliver ikke uændret $\mathbf{i}$ det nye sprog. Ligesom låneord forandres de $i$ tidens løb efter det nye sprogs regler. De fremmede lyde erstattes af omtrent enslydende egne. Den samme ændringstendens gælder også for bøjningssystemet. Folkeetymologien forandrer stednavnenes udseende, så at de fremtræder som egne. Det må derfor også være stednavneforskningens opgave at iagttage og beskrive denne udvikling, særlig $i$ grænseegne. Med hensyn til metoden er dette sket på forbilledlig måde $i$ de tysk-slaviske grænseegne i $\emptyset$ strig og Bøhmen, men også ved den flamsk-vallonske sproggrænse i Belgien. Man burde også anvende disse metoder her $\mathbf{i}$ grænselandet. Her vil jeg kun tage nogle torp-navne og nogle stednavne på -by op til behandling i sammenhæeng med sprogskiftet.

Navnene med efterleddet gammeldansk (gldsk.) -thorp ender nutildags på -rup, -drup, -trup, men i det nordlige Sydslesvig* og i Svans møder vi stednavne, som ender på højtysk -dorf, nedertysk -dörp, f. eks. Busdorf, Fahrdorf, Basdorf, Saxtorf og Geltorf. De nedertyske dialektformer er Busdörp, Fårdörp, Båsdörp, Saxdörp og Geldörp. Den måde forled og efterled er sat sammen på, viser tydeligt, at de nævnte stednavne er af dansk oprindelse ${ }^{1}$ ),

* Ordet er her brugt i sin gamle videnskabelige betydning: landet syd for Sli-Danevirke. 
men de danske officielle former af disse stednavne som vi finder dem f. eks. hos Johs. Kok (Det danske Folkesprog i Sønderjylland, 1863-67) og Trap (Stat.top. Beskrivelse af Hertugd $ф m-$ met Slesvig, 1864): Bastorf, Fartorp, Saxtorf, Lottorf eller Bystorp (i Svans) viser, at de er overtaget fra tysk. De går ikke tilbage til gamle danske stedmålsformer som i Angel eller Mellemslesvig, f. eks. Brarup, Sterup og Sillerup. Vi kan altså ved hjælp af efterleddet nedertysk -dörp, højtysk -dorf i oprindelige danske slednavne i Sydslesvig og Svans se, at den danske sprogudvikling $i$ disse egne er afbrudt allerede $i$ slutningen af middelalderen. Vi ved jo også, at det danske sprog her i det nordlige Sydslesvig og i Svans blev aflø̧st af nedertysk på denne tid. Kun i Bustrup har vi en dansk form ined regte tradition.

I Angel og Mellemslesvig stemmer de danske og de højtyske og nedertyske former for torp-navne for storstedelen overens, f. eks. Stenderup, Munkbrarup og Olderup. Her er vi jo i egne, hvor sprogskiftet f $\varnothing$ rst har fundet sted i løbet af de sidste hundrede år.

Vi kan dog også i Angel og Mellemslesvig finde stednavneformer, som ligner de sydslesvigske. Vi begynder med Gottorp, således dansk og nedertysk, højtysk: Gottorf. Slottets navn går jo tilbage til et stednarn, der egentlig hører hjemme $i$ egnen nord for Slesvig. Det skyldes vel slottets betydning som tyskpræget residens, at den nedertyske form er trængt igennem også i dansk sprogbrug. Middelalderlige former på -torp kunne også være danske, men at denne form bevares til nutiden skyldes vel en nedertysk påvirkning. Det må beklages, at den officielle tyske sprogbrug nutildags ikke anvender den vante form Gottorp, som er kendt som den almindelig brugte langt uden for Slesvig-Holsten. En agte angeldansk form - Guderup og en ældre Gotterup ikke for det nuvarende slot, men for dets forgenger Gammel(rottorp nord for Slesvig ved godset Falkenberg, anf $\phi$ res af A. Sach").

I det nord $\phi$ stlige Angel tiltrækkes vor opmærksomhed af Snakketorp og Vippetorp i deres egenskab af torp-navne i vor sammenhæng. De nedertyske former er Schwackendörp og Wippendörp, de højtyske Schwackendorf og Wippendorf. Her finder 
vi ikke, som vi er vant til i Angel, efterleddet -rup, -trup eller -drup, men som i Sydslesvig og Svans det tyske -dorf, nedertysk -dörp. Desuden lægger vi marke til den i disse egne uvante tyske svage ejefalds-b $\phi$ jningsform -en i sammensatningen, f. eks. Brekendorf eller Krusendorf, i modsætning til gldsk. *Svakkathorp (1231 i Kong Valdemars Jordebog fejlskrevet Rackiethorp) og Vippathorp (1231 smst.) Den tyske svage bøjningsform på -en ( $\mathrm{i}$ modsatning til gldsk. - $x$, der er udviklet af olddansk $-a$, f. eks. oldnordisk hani, hana, mens tysk har f.eks. der Graf,des Grafen' ved Schwackendorf og Wippendorf kender vi allerede fra middelalderlige dokumenter, 1436 Swackendorp, 1352 Wippendorp. De officielle danske former Suakketorp og rippetorp kender ilke denne tyske svage bqjningsendelse $i$ sammensatningen. Derimod kan de ikke med efterleddet -torp gâ tilbage til en folkelig dansk form, men som det er tilfaldet i Sydslesvig og Svans og ved Gottorp er de påvirket af den nedertyske form. Sandsynligvis må vi her regne med en gammel starkere nedertysk tradition, der kan gå tilbage til et mere udbredt nedertysk omgangssprog på godserne ${ }^{8}$. Da vi ikke længere kender tilsvarende angeldanske former, kan vi kun udtale gisninger.

De фvrige torp-navne $\mathrm{i}$ Angel ender som sagt på -rup, -drup eller -trup, med undtagelse af de officielle tyske former Struxdorf, Schrixdorf og Tösdorf. Det første navn hedder på rigsdansk som vi kunne vente, Strukstrup. Den angeldanske form lyder i overensstemmelse hermed Strustrup. Således hedder byen if $\emptyset$ lge Müllenhoff, Mensing og Selk også på nedertysk, men i dag kan man allerede høre Struxdörp, vel på grundlag af den officielle højtyske form Struxdorf. Skredstrup, højtysk Schrixdorf kendes pá nedertysk som Schreistrup. Denne form går sandsynligvis tilhage til et angeldansk *Skrejstrup. Tøstrup findes på tysk i to forskellige officielle former. Godset hedder Töstorf, mens sognet hedder Töstrup.

Fn lignende udvikling som i Sydslesvig og Srans har vi i det vestlige Slesvig, i Nordfrisland. Her interesserer vi os kun for den frisiske del af Nørreg $\phi$ sherred, for i denne egn er torpnavnene af dansk oprindelse. De ender $i$ dag $i$ de officielle $h \phi j-$ tyske former på -dorf on $\mathrm{i}$ de nedertyske folkelige former på 
-dörp, f. eks. højtysk Almdorf, Riddorf og Drelsdorf, nedertysk Almdörp, Riddörp og Drelsdörp. Her må vi huske, at befolkningen i disse egne var frisisk-talende sandsynligvis siden højmiddelalderen eller lidt senere. Ligesom højtysk og nedertysk bruger nordfriserne her $\mathrm{i}$ den frisiske del af Nørregøsherred som efterled til torp-navnene det tilsvarende ord i deres eget sprog, f. eks. Almtorp og Trälstorp, men også ved de danske stednavne uden for det frisiske sprogområde, f. eks. Brüdtorp (Braderup i Kar Herred) og Bjarntorp (Bjerndrup). En direkte overtagelse af den danske form kan vi derimod iagttage ved Altrop, Altrop (Olderup), Brererep (Braderup på Sild) og Trellstrup eller Trålstrup ved siden af Trälstorp og Reserup eller Röserup (tysk Riddorf). Også tyske former følger de danske f. eks. Olderup, nedertysk Ollerup, og Braderup. Af de førstnævnte stednavne har Fjolde-målet endnu bevaret de ægte danske former, f. eks. Trælstrup og Almstrup. Den sidste form har her et senere tilkommet sammensætnings-s. Også Ridderup kendes som dansk form svarende til tysk Riddorf. Drelstrup, altså efter det danske, siger man også på nedertysk i Fjolde-egnen, i et område hvor sprogskiftet f $\varnothing$ rst har fundet sted inden for de sidste 50 år. Derimod har vi i dag i stedet for Bjerndrup som i Sydslesvig og Nordfrisland den rent nedertyske form Beerndörp, højtysk Behrendorf, svarende til Wippendörp, Schwackendörp og Struxdörp i Angel.

En lignende udvikling kan vi også iagttage ved nogle by-navne. Efterleddet $-b y$ udtales på tysk tit med afrundet vokal som $-b i$, f. eks. šu:bi $\cdot\left(\right.$ Skovby, tysk: Schuby) og $x e \cdot$ lbi $^{\prime}$ hold $^{4}$ ) (Geelbyholt). I det sydlige Slesvig støder vi på nedertyske dialektformer som Güf, Göf og Nörf for Gyby, Gøteby og Norby. Som i de ovenfor nævinte tilfælde er efterleddet $-b y$ blevet til $-b i^{\prime}$ og derefter fuldstændig afslidt. Men det udlydende $b$ udtales ikke som lukkelyden $b$, men som gnidelyden $f$. Noget tilsvarende kendes fra s $\varnothing n$ derjysk: gab - gaf, skib - skif. En parallel udvikling, hvor et helt led reduceres til en enkelt lyd, har vi i de to nedertyske stednavne Schülp i Holsten, ét ved Nortorf og ét ved Jevenstedt, 12. og 13. århundrede Scullebi, 1320 Scullebe, 1517 Schulpe, og 1150 Scullebi. Dette stednavn er ofte blevet tolket som et by-navn, men er imidlertid sammensat med nedertysk $B \ddot{a}, B \ddot{j} j, B \ddot{u}:$ s $\emptyset \emptyset j-$ 
ning, lavland langs en flod «. Da Gyby, Gøteby og Norby ligger i et område, der meget tidligt blev nedertysk er det let at forstå, at den lydudvikling der gjaldt i Holsten også kom til at virke her.

1) W. Laur, Die Verdeutschung dänischer Ortsnamen im ehemaligen Herzogtum Schleswig. (I: Beiträge zur Namenforschung 11, 1960, s. 135); Die Ortsnamen in Schleswig-Holstein, Gottorfer Schriften VI, Schleswig 1960, s. 57 og Die Ortsnamen im Landesteil Schleswig. I: Geschichte Schleswig-Holsteins Bd. 3, Neumünster 1957, s. 163.

2) W Laur: Gottorf. (i: DIE HEIMAT, 1955, bd. 62, s. 190-91).

s) C: F. Allen: Die Geschichte der dänischen Sprache im Herzogthum Schleswig I, 1857, s. 181 og II, 1858, s. 70.

4) $\check{s}$ som tysk sch. $x$ som $g$ i s $\phi$ nderjydsk kage (kar $x$ ). 